\title{
Faecal Escherichia coli as biological indicator of spatial interaction between domestic pigs and wild boar (Sus scrofa) in Corsica
}

\author{
S. A. Barth ${ }^{1}$ \\ S. Blome ${ }^{2}$ \\ D. Cornelis ${ }^{3}$ \\ J. Pietschmann ${ }^{1,2}$ \\ M. Laval ${ }^{4}$ \\ O. Maestrini ${ }^{4}$ \\ L. Geue ${ }^{1}$ \\ F. Charrier ${ }^{4}$ \\ E. Etter ${ }^{3,5}$ \\ C. Menge ${ }^{1}$ \\ M. Beer ${ }^{2}$ (D) । \\ F. Jori ${ }^{3,6}$
}

${ }^{1}$ Institute of Molecular Pathogenesis, Friedrich-Loeffler-Institut/Federal Research Institute for Animal Health, Jena, Germany

${ }^{2}$ Institute of Diagnostic Virology, FriedrichLoeffler-Institut/Federal Research Institute for Animal Health, Greifswald - Insel Riems, Germany

${ }^{3}$ CIRAD, UMR ASTRE, INRA, University Montpellier, Montpellier, France

${ }^{4}$ Research Unit for Animal Husbandry Development (LRDE), INRA SAD, Corte, Corsica, France

${ }^{5}$ Epidemiology Section, Department of Production Animals Studies, Faculty of Veterinary Science, University of Pretoria, Onderstepoort, South Africa

${ }^{6}$ Department of Animal Science and Production, Botswana College of Agriculture, Gaborone, Botswana

\section{Correspondence}

S. Barth, Institute of Molecular Pathogenesis, Friedrich-Loeffler-Institut/Federal Research Institute for Animal Health, Jena, Germany. Email: stefanie.barth@fli.de

Funding information

Seventh Framework Programme, Grant/ Award Number: 311931 (ASFORCE)

\begin{abstract}
Summary
On the Mediterranean island of Corsica, cohabitation between sympatric domestic pigs and Eurasian wild boar (Sus scrofa) is common and widespread and can facilitate the maintenance and dissemination of several pathogens detrimental for the pig industry or human health. In this study, we monitored a population of free-ranging domestic pigs reared in extensive conditions within a 800-ha property located in Central Corsica which was frequently visited by a sympatric population of wild boar between 2013 and 2015. We used GPS collars to assess evidence of a spatially shared environment. Subsequently, we analysed by PFGE of Xbal-restricted DNA if those populations shared faecal Escherichia coli clones that would indicate contact and compared these results with those collected in a distant (separated by at least $50 \mathrm{~km}$ ) population of wild boar used as control. Results showed that one of eight wild boars sampled in the study area shed E. coli Xbal clones identical to clones isolated from domestic pig sounders from the farm, while wild boar populations sampled in distant parts of the study area shared no identical clone with the domestic pigs monitored. Interestingly, within the sampled pigs, two identical clones were found in 2013 and in 2015, indicating a long-time persisting colonization type. Although the method of isolation of E. coli and PFGE typing of the isolates requires intensive laboratory work, it is applicable under field conditions to monitor potential infectious contacts. It also provides evidence of exchange of microorganisms between sympatric domestic pigs and wild boar populations.
\end{abstract}

\section{KEYWORDS}

biological contact marker, domestic pig, Escherichia coli, field study, transmission, wild boar

\section{1 | INTRODUCTION}

Wild boar and domestic pigs belong to the same species (Sus scrofa) and are known to interact when they meet in the open landscape. Such interactions have been observed on different continents (Jori,
Payne et al., 2017; Meng, Lindsay, \& Sriranganathan, 2009) and are known to be responsible for the maintenance and dissemination of several important pig pathogens, including bacteria (Richomme et al., 2013), viruses (Albina et al., 2000; Ruiz-Fons, Segalés, \& Gortázar, 2008) and parasites (Richomme, Lacour et al., 2010). Transmission of 
pathogens between both pig populations might occur via physical contact (e.g., breeding, fighting) or indirectly by sharing the same contaminated habitat. The occurrence and analysis of these interactions can be assessed through different methods including questionnaires among stakeholders (Kukielka et al., 2016; Trabucco et al., 2014), serology (Wyckoff, Henke, Campbell, Hewitt, \& VerCauteren, 2009), molecular methods (Jori et al., 2016), telemetry combined with data loggers (Pepin et al., 2016) or camera traps (Kukielka et al., 2016). Escherichia coli has been similarly used in several mammalian species, for example, to assess interactions between sympatric wild and domestic populations or individuals sharing the same environment (Mercat et al., 2016; Rwego, Isabirye-Basuta, Gillespie, \& Goldberg, 2008; Springer, Mellmann, Fichtel, \& Kappeler, 2016; VanderWaal, Atwill, Isbell, \& McCowan, 2014). It is assumed that social interactions can facilitate the exchange of microorganisms that are likely to influence the composition of the gut microbiome within a population of individuals cohabiting the same environment (Springer et al., 2016; VanderWaal et al., 2014). Therefore, genetic similarities in the gut microbiome between different populations can be used to infer direct or indirect interactions that could facilitate exchange of microorganisms, including pathogen spread. In the case of pig species, this method was recently assessed experimentally and it was demonstrated that at least in captivity, indirect contact between wild boar and domestic pigs is traceable by faecal E. coli isolates (Barth et al., 2017). However, application of this method in the field has never been tested. In this study, we attempted to assess whether faecal $E$. coli could be used as an indicator of infectious contacts as well as potential pathogen transmission between a population of free-ranging domestic pigs reared in traditional extensive Corsican conditions and a population of sympatric, free-ranging wild boar

For this purpose, we selected an extensive traditional pig farm located in Central Corsica where interactions between domestic pigs and natural populations of wild boar were commonly reported (Jori, Relun et al., 2017). To assess the occurrence of potential interactions between the two pig populations, telemetry methods were used. In addition, E. coli isolates from faecal samples of the domestic pig populations were analysed and compared with faecal E. coli isolates from wild boar individuals collected either in the same farm or from another population of wild boar living in a distant location. The latter were used as a control group for comparison.

\section{2 | MATERIAL AND METHODS}

\subsection{Study area}

Corsica is a French Mediterranean island located off the western shores of the Italian peninsula, approximately $11 \mathrm{~km}$ north of the Italian island of Sardinia. Pig breeding and production are mainly conducted in traditional free-range farming systems, which are stretched out over large surface areas with a median size of $557 \mathrm{~km}^{2}$ (Dubost, 2001), encompassing a mosaic of mountainous pastures and plain areas. Traditionally, Corsican pig production takes advantage of outdoor resources (chestnuts, acorns, etc.) to produce cured pork quality products (Relun et al., 2015). Pig farming systems are, thus, characterized by more than 100-ha large areas of pasture, with heterogeneous vegetation (i.e., Mediterranean shrubs/ bushes, chestnut and oak areas) as well as a high degree of variation in the landscape (i.e., altitude, sun exposure, vegetation and slopes).

Localization of pig groups in this large and diverse territory varies during the course of the year. During the winter months when natural resources are scarcer, they tend to remain close to the farm for supplementary feeding and reproduction. During autumn and early winter (coinciding with the chestnut harvesting period), free-ranging sounders are left in the mountain plains. This is a key moment for the animals to achieve the physiological and nutritional condition required to produce high-quality cured pork products (quality of the fat, taste of the products). Wild boar are generally present in the forested areas of the farm territory (close to the farm settlement or in the mountains) all year round. Although domestic pig-wild boar interactions are more regularly observed during autumn and early winter (Jori, Relun et al., 2017; Trabucco et al., 2014), the presence of wild boar close to the animals near the farm settlement remains important all year round (Trabucco et al., 2014). Wild boar hunting is a well-established and culturally rooted activity in Corsica (8\%-10\% of the population practices hunting), with around 30,000 wild boars hunted annually (ONCFS, 2012).

Our study area was located in a typical extensive farm, housing a population of 600 free-ranging pigs from the local "Nustrale" breed, reared to produce high-quality cured pork products. It is located in the village of Ucciani, Corse-du-Sud Department, Southern part of Corsica (Figure 1) and representative of the traditional extensive large-scale pig production. Vegetation in this area is typical for Mediterranean mountains and mainly composed of oak (Quercus ilex) thickets interspersed by chestnut trees (Castanea sativa) and beech (Fagus sylvatica). The study farm encompassed a territory of 800 ha with altitudes ranging between 270 and $1,650 \mathrm{~m}$ above sea level. During the summer period, pig herds are kept around the farm facilities ( $270 \mathrm{~m}$ in altitude), fed by the farmer, whereas during autumn and winter, pig herds are spread out over the entire area. To minimize possible interactions between wild boar and reproductive sows, all reproduction and piglet management handling (e.g., female castration) were performed before autumn (De Sainte-Marie \& Casabianca, 1998; Relun et al., 2015).

\section{2 | Telemetry protocol}

\subsection{1 | Wild boar}

Nine adult wild boar were captured with corral traps and equipped with a GPS-GSM collar between June and August 2013. In the Mediterranean area, summer is a period of food scarcity, thus favourable for baiting and capturing wild boar. Baiting started in June 2013 using maize and automatic feeders hanging over six corral traps located in the farm rangeland (Figure 1). Corral traps were 


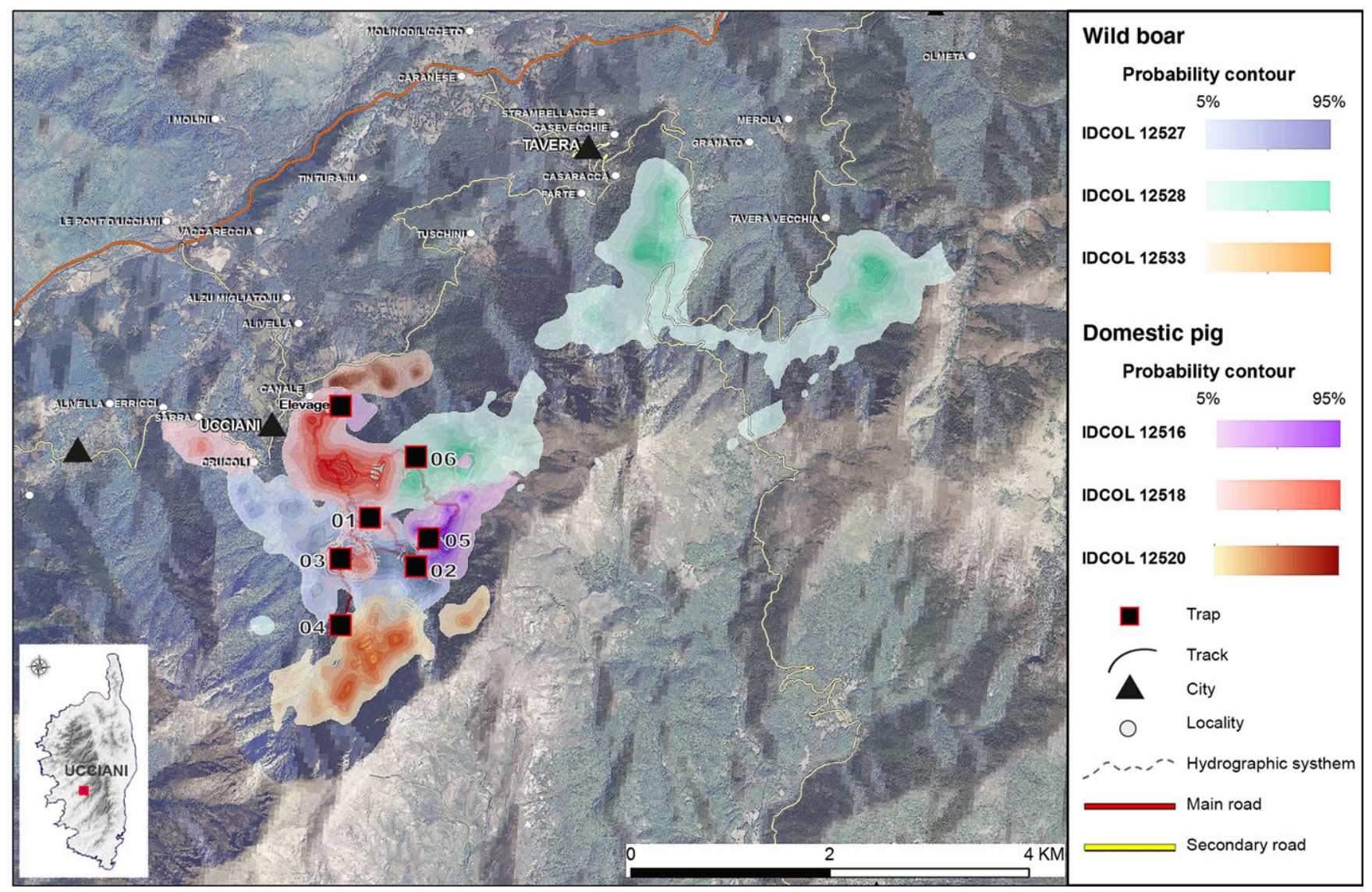

FIGURE 1 Map showing the study area, its location in Corsica, the position of the traps where the wild boar were captured and the home range contours on a sample of three wild boar and three domestic pigs

adapted from a standard design recommended by the French Office for Hunting and Wildlife (ONCFS, 2012). The attendance of the traps by wild boar was monitored using camera traps. Pictures taken by cameras were sent in real time on an e-mail server shared by the capture team. Trapped individuals were tele-anesthetized (Zoletil $100^{\circledR}$, Virbac, Carros, France) from a short distance with pistols (Dan-Inject ApS, Børkop, Denmark), blood sampled, eartagged, equipped with a GPS-GSM collar (Vectronic Aerospace $\mathrm{GmbH}$, Berlin, Germany) and released from the corral trap once completely awake. GPS-GSM collars were scheduled to acquire locations at 1-hr fix intervals. The field operations conformed to French legal requirements regarding capture and tracking protocols on large ungulates (Prefectural order No 2013-200-0006 dated July 2013 authorizing the capture of wild boar for scientific purposes in Corsica). Success rates for collared pigs were calculated as the ratio between the number of successfully acquired GPS locations compared to the total number of locations expected during the focal period.

\subsection{2 | Domestic pigs}

Early October 2013, that is, just before the chestnut and acorn period, 10 adult domestic sows were fitted with similar GPS-GSM collars also scheduled to acquire locations at 1-hr fix intervals.

\section{3 | Faecal sampling}

\subsection{1 | Wild boar}

Of the nine wild boars captured in corral traps, eight were sampled for faecal material directly from the rectum when they were immobilized (sounder $\mathrm{WB}_{\mathrm{GPS}}$ ).

In addition, a total of 47 faecal samples (sounder $W_{B_{\text {control }} \text { ) were }}$ collected during the hunting season between November 2014 and February 2015 in a hunting area located $50 \mathrm{~km}$ away from the study farm. Those samples served as controls to be compared with samples from the wild boar monitored in our study area.

\subsection{2 | Domestic pigs}

Seven of the 10 domestic sows equipped with collars (group DPo) were sampled for faecal material during the tracking period. In addition, starting in October 2014, two groups (adult sows with their piglets) were monitored longitudinally for the presence of faecal E. coli. Both sows were sampled when giving birth. Their piglets were monitored four times: at birth $\left(T_{0}\right)$ and subsequently at $\mathrm{T}_{0}+1$ month, $\mathrm{T}_{0}+3$ months and $\mathrm{T}_{0}+4$ months. Sow 1 gave birth to four piglets on 17 October 2014, resulting in 21 faecal samples (group $\mathrm{DP}_{1}$ ). Sow 2 gave birth to three piglets on 9 February 2015, 
resulting in 12 faecal samples (group $\mathrm{DP}_{2}$ ). Faecal samples from domestic pigs were collected directly from the ground shortly after defecation and stored at $-80^{\circ} \mathrm{C}$ until shipping on ice to FLI (Friedrich-Loeffler-Institut) in Germany for subsequent analysis.

\subsection{Isolation of coliform bacteria}

The quantification and isolation of coliform bacteria from the faeces as well as the storage of single colonies were performed as described previously (Barth et al., 2017). Briefly, up to ten putative E. coli isolates were isolated from each faecal sample according to the colony morphology on MacConkey, Gassner and sheep blood agar (Sifin Diagnostics $\mathrm{GmbH}$, Berlin, Germany). Due to the detection limit of $100 \mathrm{cfu} / \mathrm{g}$ faeces, the number of isolates per faecal sample varied from 0 up to 10 . Overall, $731 \mathrm{E}$. coli isolates were analysed; 327 and 404 isolates were from domestic pigs and from wild boar, respectively.

\section{5 | Analysis of PFGE patterns of restricted DNA from $E$. coli isolates}

Contour-clamped homogeneous electric field-pulsed-field gel electrophoresis (CHEF PFGE) and cluster analysis were performed as previously described (Barth et al., 2017; Geue et al., 2010). In addition to restriction with $\mathrm{Xbal}$, selected agarose plugs were digested with $15 \mathrm{U}$ Avall or $15 \mathrm{U}$ Spel (New England Biolabs GmbH, Frankfurt/Main, Germany) at $37^{\circ} \mathrm{C}$ (Spel $18 \mathrm{hr}$, Avall $5 \mathrm{hr}$ ). For separation of Avall- or Spel-digested DNA fragments, the pulse times in the CHEF Mapper XA system increased from 6.75 to $35.38 \mathrm{~s}$ with a gradient of $6 \mathrm{~V} / \mathrm{cm}$ and a constant angle of $120^{\circ}$ during $19 \mathrm{hr}$. Interpretation of PFGE patterns was performed by visual inspection and computer analysis with Bionumerics (version 6.6; Applied Maths NV, Sint-Martens-Latem, Belgium). Distance matrices were calculated by pairwise comparisons of the fragment patterns produced by the restriction endonucleases used for the PFGE analysis including DNA fragments between 49 and $630 \mathrm{~kb}$ length (Lambda Ladder PFGMarker, New England Biolabs). The cluster analysis of the
Xbal-fragmented DNA was based on the Dice algorithm with $2.0 \%$ tolerance and $0.5 \%$ optimization and the unweighted pair group method with arithmetic mean (UPGMA).

\section{6 | Data analysis}

Significant differences in the mean numbers of $E$. coli isolates and identified PFGE clones were calculated using IBM SPSS Statistics (version 19.0.0.2; IBM Deutschland GmbH, Ehningen, Germany).

The relationships between animals based on shared $E$. coli clones were analysed by social network analysis (SNA). According to SNA vocabulary, the wild and domestic suids represent the vertices and each shared E. coli Xbal clone represents an edge of the network. Specific network parameters (density, diameter, k-core) were calculated, and graphs were first performed using $\mathrm{R}$ (version 3.3.3) with the igraph package (version 0.7.1) ( $R$ Core Team, 2016). The k-core is the maximal subgraph in which each vertex is adjacent to at least $\mathrm{k}$ other vertices of the subgraph (Fortunato, 2010). For a better reproduction quality of the captions, the graphs were subsequently edited using Microsoft PowerPoint (version 2016) software.

Geospatial analysis focused on a period starting in October 2013 for 3 months (autumn and early winter) using movement data from six domestic pigs and four wild boars. Beyond this period, sample size decreased drastically due to collar losses, collar failures or individual mortality (due to hunting). During the focal period, GPS collars returned data with success rates of $59.3 \pm 26.4 \%$ from domestic pigs and $48.5 \pm 33.2 \%$ wild boar (mean $\pm S D$ ), respectively (Table 1). Spatial behaviour of GPS-tracked individuals was characterized by computing home range area, the distance between the barycentres of the home range and the farm buildings, and the daily distances ranged. Home ranges were computed (up to the 0.95 isopleth) for each collared individual using a movement-based kernel density estimation method (Benhamou \& Cornélis, 2010). Daily distances ranged by GPS-tracked individuals were calculated using 24hr time series during which at least $80 \%$ of the expected GPS locations were acquired. We then computed home range overlaps to quantify the extent to which the collared individuals shared space.

TABLE 1 Telemetry protocol summary

\begin{tabular}{|c|c|c|c|c|c|c|c|c|c|}
\hline Pigs & Collar ID & Sex & $\begin{array}{l}\text { Age } \\
\text { (months) }\end{array}$ & Start tracking & End tracking & $\begin{array}{l}\text { Success } \\
\text { rate (\%) }\end{array}$ & $\begin{array}{l}\text { Distance by } \\
24 \mathrm{hr}(\mathrm{km} \pm S D)\end{array}$ & $\begin{array}{l}\text { Distance from } \\
\text { farm }(\mathrm{km})\end{array}$ & $\begin{array}{l}\text { Home } \\
\text { range }\left(\mathrm{km}^{2}\right)\end{array}$ \\
\hline \multirow[t]{4}{*}{ Wild boar } & 528 & $M$ & 24 & 02/10/13 & 01/01/14 & 40 & $3.5 \pm 1.3$ & $3.8 \pm 1.9$ & 4.6 \\
\hline & 533 & $\mathrm{~F}$ & 36 & $02 / 10 / 13$ & $02 / 01 / 14$ & 12 & $1.9 \pm 0.1$ & $2.4 \pm 0.3$ & 0.8 \\
\hline & 534 & $M$ & 36 & $02 / 10 / 13$ & $01 / 01 / 14$ & 50 & $3.2 \pm 1.5$ & $1.2 \pm 0.5$ & 3.3 \\
\hline & 536 & $\mathrm{~F}$ & 36 & $02 / 10 / 13$ & $02 / 01 / 14$ & 92 & $1.8 \pm 0.8$ & $1.5 \pm 0.2$ & 0.6 \\
\hline \multirow[t]{6}{*}{ Domestic pigs } & 516 & $\mathrm{~F}$ & 60 & $02 / 10 / 13$ & $02 / 01 / 14$ & 93 & $1.6 \pm 0.6$ & $1.2 \pm 0.6$ & 0.8 \\
\hline & 518 & $\mathrm{~F}$ & 30 & $02 / 10 / 13$ & $21 / 12 / 13$ & 77 & $2.5 \pm 0.9$ & $0.6 \pm 0.4$ & 1.9 \\
\hline & 519 & $\mathrm{~F}$ & 48 & $16 / 10 / 13$ & $14 / 11 / 13$ & 37 & $1.8 \pm 0.6$ & $0.8 \pm 0.4$ & 1.0 \\
\hline & 520 & $\mathrm{~F}$ & 60 & $16 / 10 / 13$ & $10 / 11 / 13$ & 30 & $1.5 \pm 0.7$ & $0.3 \pm 0.3$ & 0.4 \\
\hline & 521 & $\mathrm{~F}$ & 24 & $02 / 10 / 13$ & $15 / 12 / 13$ & 78 & $1.7 \pm 0.8$ & $0.3 \pm 0.2$ & 0.6 \\
\hline & 522 & $\mathrm{~F}$ & 24 & $02 / 10 / 13$ & $10 / 11 / 13$ & 41 & $0.7 \pm 0.6$ & $0.1 \pm 0.0$ & 0.3 \\
\hline
\end{tabular}


Home range overlaps were computed using a volume index ranging between 0 (no area shared) and 100\% (identical utilization distributions) (Germain, Benhamou, \& Poulle, 2008).

\section{3 | RESULTS}

\subsection{Space use and space sharing behaviour}

GPS-tracked wild boar displayed home ranges of $2.3 \pm 1.9 \mathrm{~km}^{2}$ (mean $\pm S D$; Table 1) located on average $2.2 \pm 0.7 \mathrm{~km}$ from the farm buildings (Figure 1). In contrast, domestic pigs displayed home ranges of $0.8 \pm 0.6 \mathrm{~km}^{2}$ located on average $0.5 \pm 0.3 \mathrm{~km}$ from the farm buildings. Wild boar and domestic pigs covered daily distances of $2.6 \pm 0.9 \mathrm{~km}$ and $1.6 \pm 0.7 \mathrm{~km}$, respectively. Home range overlap estimations show that the highest amounts of space sharing were reached within the domestic pig population $(19.7 \pm 16.4 \%$, mean $\pm S D$ ). Lower amounts of space sharing were observed in the wild boar population of (11.2 $\pm 14.9 \%)$ and even less between wild and domestic populations $(6.9 \pm 12.5 \%)$ (Table 2$)$.

\section{2 | Isolation of $E$. coli}

By cultivation of faecal samples on Gassner and MacConkey agar, coliform bacteria were detected in 84 of 95 samples (Table 3). The number of coliform bacteria [cfu/g faeces] ranged from 0 to $5.6 \times 10^{8}$ for wild boar and from 0 to $1.4 \times 10^{9}$ for domestic pigs (Table 3). Overall, the number of coliform bacteria from wild boar and domestic pigs did not differ significantly (Mann-Whitney $U$ test, $p=.099$ ). However, the individual groups and sounders showed significantly different loads of bacteria. The lowest average number was detected in faecal samples from group $\mathrm{DP}_{0}$, while the samples from pigs of group $\mathrm{DP}_{2}$ shed the most coliform bacteria (Table 3; Kruskal-Wallis test, $p \leq .028$ ).

Altogether, we picked 817 colonies from 84 samples positive for coliform bacteria. Thereof, 731 colonies also displayed the expected coliform colony morphology on sheep blood agar and were therefore assumed to be $E$. coli isolates. The number of $E$. coli isolates obtained per sample did not differ significantly between the groups or sounders (Table 3; Kruskal-Wallis test, $p=.231$ ).

\subsection{Genetic relatedness of the E. coli isolates}

Of $731 \mathrm{E}$. coli isolates, $323 \mathrm{E}$. coli with individual profiles were detected by Xbal restriction and PFGE analysis resulting in 315 distinct $E$. coli clones when excluding isolates found more than once per individual faecal sample $(>95 \%$ similarity or $\leq 3$ different fragments; Tenover et al. (1995); Figure S1). Pigs from group $D_{1}$ possessed the most heterogeneous composition of $E$. coli with 5.86 clones per sample on average (Table 3). This number was significantly different from the mean number of clones in both wild boar sounders and group $\mathrm{DP}_{2}$ (Kruskal-Wallis test; $p \leq .032$ ).

Comparing the $315 \mathrm{E}$. coli clones, we found 221 clones only once (less than 95\% similarity to other clones), while 94 clones formed 36 clusters (clones that share restriction patterns with more than $95 \%$ similarity) with two to six members (Figure S1). Most clusters $(n=27)$ contained clones from one group or sounder (Table 4). Twenty-five clusters were formed by clones only present in domestic pigs (15 clusters with clones from group $\mathrm{DP}_{1}$, four clusters with clones from $\mathrm{DP}_{2}$, five clusters with clones from $\mathrm{DP}_{1}$ and $\mathrm{DP}_{2}$ and one cluster with clones from $\mathrm{DP}_{0}$ and $\mathrm{DP}_{1}$ ), whereas eight clusters contained only clones from the wild boar group $\mathrm{WB}_{\text {control. }}$ Three clusters comprised identical clones from wild boar $\left(\mathrm{WB}_{\mathrm{GPS}}\right)$ and domestic pigs $\left(D_{1}\right)$. The respective clones were found to be identical after Xbal restriction and after additional Avrll and Spel restriction (Figure 2).

Upon visualizing the results in a network, it became clear that, regardless of the number of clones per sample, some samples (animals) shared identical clones with several other samples (animals) also of other groups or sounders (Figure 3). Overall, in the network, we detected 68 interrelations between two individual samples based on the identification of one or up to three shared $E$. coli clones per interrelation. The highest number of interrelations was found in one sample sharing $E$. coli clones with seven other samples followed by
TABLE 2 Spatial overlaps of domestic pigs and wild boar as determined by GPS collars

\begin{tabular}{|c|c|c|c|c|c|c|c|c|c|}
\hline & \multicolumn{9}{|c|}{ Home range overlap matrix (\%) } \\
\hline & \multicolumn{3}{|c|}{ Wild boar } & \multicolumn{6}{|c|}{ Domestic pigs } \\
\hline & W533 & W534 & W536 & D516 & D518 & D519 & D520 & D521 & D522 \\
\hline \multicolumn{10}{|l|}{ Wild boar } \\
\hline W528 & 0 & 23 & 6 & 5 & 7 & 4 & 0 & 0 & 0 \\
\hline W533 & - & 1 & 1 & 1 & 2 & 1 & 0 & 0 & 0 \\
\hline W534 & - & - & 36 & 20 & 11 & 23 & 3 & 1 & 0 \\
\hline W536 & - & - & - & 53 & 7 & 27 & 0 & 0 & 0 \\
\hline \multicolumn{10}{|c|}{ Domestic pigs } \\
\hline D516 & - & - & - & - & 8 & 15 & 7 & 9 & 8 \\
\hline D518 & - & - & - & - & - & 51 & 6 & 48 & 20 \\
\hline D519 & - & - & - & - & - & - & 2 & 33 & 11 \\
\hline D520 & - & - & - & - & - & - & - & 9 & 26 \\
\hline D521 & - & - & - & - & - & - & - & - & 42 \\
\hline
\end{tabular}


TAB LE 3 Faecal samples, E. coli isolates and identified PFGE clones

\begin{tabular}{|c|c|c|c|c|c|c|c|c|}
\hline \multirow[b]{2}{*}{ Pigs } & \multirow[b]{2}{*}{ WB sounder/DP group } & \multirow{2}{*}{$\begin{array}{l}\text { Sampling of } \\
\text { faeces (per } \\
\text { animal, time } \\
\text { range) }\end{array}$} & \multicolumn{2}{|c|}{ Coliform bacteria } & \multicolumn{2}{|c|}{ E. coli isolates ${ }^{\dagger}$} & \multicolumn{2}{|c|}{ 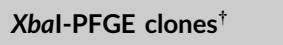 } \\
\hline & & & $\begin{array}{l}\text { Number faecal } \\
\text { samples } \\
\text { [positive/total] }\end{array}$ & $\begin{array}{l}\text { Cfu/g faeces } \\
\text { (mean } \pm \text { SEM }[\text { min-max]) }\end{array}$ & Total & $\begin{array}{l}\text { Number } \\
\text { per sample } \\
{[\text { mean } \pm S D]}\end{array}$ & Total & $\begin{array}{l}\text { Number per } \\
\text { sample } \\
{[\text { mean } \pm S D \text { ] }}\end{array}$ \\
\hline \multirow[t]{2}{*}{ Wild boar } & $\begin{array}{l}\text { WB } \\
\text { (with GPS collar) }\end{array}$ & $\begin{array}{l}\text { Once, Jun } 2013 \\
\text { till Aug } 2013\end{array}$ & $7 / 8$ & $\begin{array}{l}5.2 \times 10^{7} \pm 3.5 \times 10^{7} \\
\left(0-2.6 \times 10^{8}\right)\end{array}$ & 64 & $7.86 \pm 2.55$ & 18 & $2.57 \pm 1.90^{\mathrm{e}}$ \\
\hline & $\begin{array}{l}\mathrm{WB}_{\text {control }} \\
\text { (without GPS collar) }\end{array}$ & $\begin{array}{l}\text { Once, Nov } 2014 \\
\text { till Feb } 2015\end{array}$ & $42 / 47$ & $\begin{array}{l}1.3 \times 10^{7} \pm 1.2 \times 10^{7} \mathrm{a}, \mathrm{b} \\
\left(0-5.6 \times 10^{8}\right)\end{array}$ & 410 & $8.31 \pm 2.51$ & 127 & $3.02 \pm 1.81^{f}$ \\
\hline \multirow[t]{3}{*}{$\begin{array}{l}\text { Domestic } \\
\text { pigs }\end{array}$} & $\begin{array}{l}\mathrm{DP}_{0} \\
\text { (young sows) }\end{array}$ & $\begin{array}{l}\text { Once, Oct } 2013 \\
\text { till Nov } 2013\end{array}$ & $3 / 7$ & $\begin{array}{l}21.4 \pm 10.1^{\mathrm{a}, \mathrm{c}, \mathrm{d}} \\
(0-50)\end{array}$ & 30 & $9.33 \pm 0.58$ & 12 & $4.00 \pm 2.00$ \\
\hline & $\begin{array}{l}\mathrm{DP}_{1} \\
\text { (sow no. } 1 \text { with } 4 \text { piglets) }\end{array}$ & $\begin{array}{l}\text { Four times, } \\
\text { Oct } 2014 \text { till } \\
\text { Feb } 2015\end{array}$ & $21 / 21$ & $\begin{array}{l}2.6 \times 10^{7} \pm 1.7 \times 10^{7 d} \\
\left(500-3.2 \times 10^{8}\right)\end{array}$ & 203 & $9.14 \pm 1.46$ & 123 & $5.86 \pm 1.96^{e, f, g}$ \\
\hline & $\begin{array}{l}\mathrm{DP}_{2} \\
\text { (sow no. } 2 \text { with } 3 \text { piglets) }\end{array}$ & $\begin{array}{l}\text { Four times, } \\
\text { Feb } 2015 \text { till } \\
\text { Jun } 2015\end{array}$ & $11 / 12$ & $\begin{array}{l}3.2 \times 10^{8} \pm 1.3 \times 10^{8 b, c} \\
\left(0-1.4 \times 10^{9}\right)\end{array}$ & 110 & $9.73 \pm 0.47$ & 35 & $3.18 \pm 1.10^{g}$ \\
\hline
\end{tabular}

DP, domestic pig; SD, standard deviation; SEM, standard error of the mean; WB, wild boar.

Identical superscript letters, significant differences between groups (Kruskal-Wallis test, $p<.05$ ).

${ }^{\dagger}$ Mean number of $E$. coli isolates; and clones are related only to positive faecal samples.

TABLE 4 Detected clusters according to the affiliation of clones to different groups and sounders

\begin{tabular}{|c|c|c|c|c|c|}
\hline & \multicolumn{5}{|c|}{$\begin{array}{l}\text { Number of cluster with clones from the different groups } \\
\text { or sounders }\end{array}$} \\
\hline & $\begin{array}{l}\text { WB }_{\text {GPS }} \\
\text { (with GPS } \\
\text { collar) }\end{array}$ & $\begin{array}{l}\text { WB }_{\text {control }} \\
\text { (without } \\
\text { GPS } \\
\text { collar) }\end{array}$ & $\begin{array}{l}\mathrm{DP}_{0} \\
\text { (young } \\
\text { sows) }\end{array}$ & $\begin{array}{l}\mathrm{DP}_{1} \\
\text { (sow } 1 \text { with } \\
4 \text { piglets) }\end{array}$ & $\begin{array}{l}\mathrm{DP}_{2} \\
\text { (sow } 2 \text { with } \\
5 \text { piglets) }\end{array}$ \\
\hline$W_{G P S}$ & 0 & 0 & 0 & 3 & 0 \\
\hline $\mathrm{WB}_{\text {control }}$ & - & 8 & 0 & 0 & 0 \\
\hline $\mathrm{DP}_{\mathrm{o}}$ & - & - & 0 & 1 & 0 \\
\hline $\mathrm{DP}_{1}$ & - & - & - & 15 & 5 \\
\hline $\mathrm{DP}_{2}$ & - & - & - & - & 4 \\
\hline
\end{tabular}

DP, domestic pigs; WB, wild boar.

Xbal-restricted DNA, dice, with $2.5 \%$ tolerance and unweighted pair group method with arithmetic mean (UPGMA). Numbers listed under the same heading for column and row refer to clusters restricted to the given animal group.

five samples sharing clones with six other samples, respectively. In particular, we found connections between animals within group $\mathrm{DP}_{1}$ or within group $\mathrm{DP}_{2}$, mostly representing one litter at one sampling point (parts A, B or C of the network). Nevertheless, connections between different groups or sounders were also determined, for example, part $D$ of the network included samples from groups $D_{1}$, $\mathrm{DP}_{2}$ and $\mathrm{WB}_{\mathrm{GPS}}$.

For statistical purposes, we analysed the global network and formed subnetworks of the groups $\mathrm{DP}_{1}, \mathrm{DP}_{2}$ and $\mathrm{WB}_{\text {control, }}$ respectively. The subnetworks were built by removal of all connections to samples of other groups. While the density of the global network (number of present of all possible interrelations) was $2.1 \%$, the density of the subnetwork $\mathrm{DP}_{1}$ was $16.2 \%$, the one formed by $\mathrm{DP}_{2}$ was $54.5 \%$, and the one consisting of the $\mathrm{WB}_{\text {control }}$ group was $0.9 \%$. The diameter of the global network (shortest path between the two furthest samples) encompassed nine other samples, the diameter of the subnetwork $\mathrm{DP}_{1}$ involved eight samples and those of $\mathrm{DP}_{2}$ and $\mathrm{WB}_{\text {control }}$ two other samples, respectively. These findings imply that E. coli clones are most likely shared by direct animal-to-animal contact in the case of $\mathrm{DP}_{2}$ (with many $E$. coli clones shared) and in $W B_{\text {control }}$ (with few E. coli clones shared), whereas animals are primarily connected indirectly, that is, through intervention of many others, in the global network and $\mathrm{DP}_{1}$. Calculating the k-cores (a maximal subgraph that contains animals having at least $k$ shared clones) and plotting them in the network, all but three samples of $\mathrm{DP}_{2}$ regrouped in the 8-core part of the network (part $\mathrm{A}$ ) reflecting the intense interconnection of those animals (samples) (Figure 4). The samples belonging to group $\mathrm{DP}_{1}$ grouped in the 5-, 4- and 3core (parts $\mathrm{D}, \mathrm{C}$ and $\mathrm{B}$, respectively), with one $\mathrm{DP}_{2}$ and one $\mathrm{WB}_{\mathrm{GPS}}$ sample being part of the 5 -core.

Additionally, while most of the clones were found only at one sampling time point, other clones were present over longer time periods. For example, one clone was found once in $2013\left(D_{0}\right)$ and again once in 2015 ( $\mathrm{DP}_{1}$; part $\mathrm{E}$ of the network) or clones in part $\mathrm{D}$ of the network sampled in 2013 (WB $\left.\mathrm{WPS}_{\mathrm{GP}}\right), 2014\left(\mathrm{DP}_{1}\right)$ and 2015 $\left(D_{1}, D_{2}\right)$ (Figure 3, Figure S1).

\section{DISCUSSION}

Historically, pig farming in Corsica is based on a traditional pastoral system with extensive outdoor free-ranging livestock. The number of pigs reared on the island is estimated to be approximately 26,360 


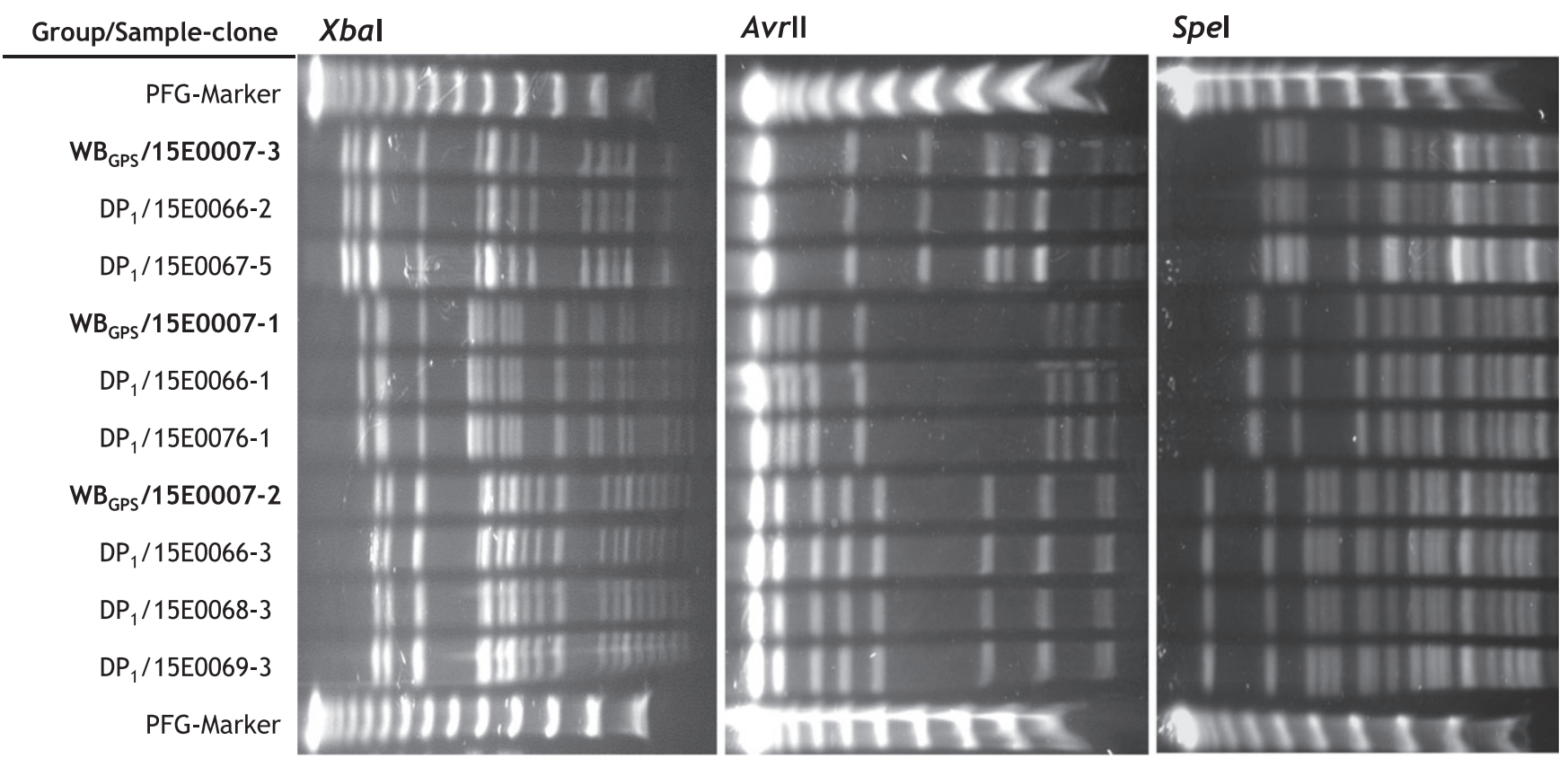

FIGURE 2 Confirmation of clonality of identical $E$. coli Xbal clones present in faeces from wild boar (sounder WB $\mathrm{BPS}_{\mathrm{GP}}$ ) and from domestic pigs (group $\mathrm{DP}_{1}$ ) by PFGE of DNA digested with Avrll and Spel. DP, domestic pigs; WB, wild boar; Marker: Lambda Ladder PFG-Marker

animals (Richomme, Lacour et al., 2010). In recent years, the development of tourism and the commercial success of high-quality cured meat products from pigs reared in free-ranging conditions has boosted and subsequently consolidated an outdoor pig production industry (Relun et al., 2015). Concurrently, the agricultural decline and abandonment of agricultural land in recent decades have led to a notable increase in wild boar populations as evidenced by the approximately 30,000 wild boars hunted annually (ONCFS, 2012). Similar to other Mediterranean locations, these conditions provide an ideal environment for the interaction between wild and domestic pig populations (Jori, Relun et al., 2017) and the subsequent maintenance and transmission of pathogens detrimental for both the pig industry (Albina et al., 2000; Mur et al., 2016) and human health (Charrier et al., 2018; Pavio et al., 2016; Richomme, Boschiroli, Hars, Casabianca, \& Ducrot, 2010). Previous work developed to collect information on interactions between wild and domestic pigs among farmers and hunters indicated a high incidence of direct contacts in extensive pig farms. These mostly resulted from sexual attraction of wild boar by domestic sows in the autumn months, while feeding interactions occurred all year round depending on fruit availability (Jori, Relun et al., 2017; Trabucco et al., 2014). Therefore, Corsican pig farming estates provide a well-characterized environment to validate shared carriage of E. coli strains as biological indicator of infectious contacts between wild boar and domestic pigs under field conditions. Our study farm had reported sexual interactions between domestic sows and wild boar, and fights between wild and domestic boar had been observed at least twice during the year preceding the study (Trabucco et al., 2014). Monitoring of spatial interactions was conducted during 3 months in autumn, which is considered a highly favourable period for sexual driven interactions between wild boar and domestic sows (Jori, Relun et al., 2017). Indeed, spatial analysis confirmed an overlap of home ranges between both populations under study, even though low GPS success rates kept us from unveiling if those interactions were through direct physical contact or by sharing the same environment. The comparative analysis of E. coli microbiota as a measure to determine potential contacts between populations of different species or within groups of the same species has been used for several mammalian species, particularly wild and domestic bovids (Mercat et al., 2016), mustelids (Pesapane, Ponder, \& Alexander, 2013), primates (Rwego, Isabirye-Basuta et al., 2008) and humans (Rwego, Gillespie, Isabirye-Basuta, \& Goldberg, 2008). Our study provides evidence for the first time that this method can also be applied successfully to domestic and wild freeranging suid populations interacting under field conditions. These interactions can be the result of direct contact between individuals, the fact of sharing the same environment contaminated with faeces (water holes or feeding sites) or also through the consumption of infected carcasses or offal remaining from infected animals (Jori, Relun et al., 2017).

Escherichia coli is an ideal candidate to monitor potential contacts between wild boar and domestic pigs, because it represents a dominant part of the aerobe microbiota in the intestine of several vertebrates, is shed in high quantities in the faeces, is genetically heterogeneous and can survive in the environment, depending on temperature and moisture, for more than 1 year (Fremaux et al., 2008; Gordon \& Cowling, 2003; Schierack, Walk, Reiter, Weyrauch, \& Wieler, 2007). Using PFGE analysis, several authors tracked single E. coli clones for several months in different species, including mallard ducks (at least 3 years [Rödiger et al., 2015]), cattle herds (at least 15 months [Geue et al., 2009; Liebana et al., 2005]) or sheep flocks (at least 11 months [Sánchez et al., 2009]). The persistence of E. coli clones in suids reported to date is based on shorter 


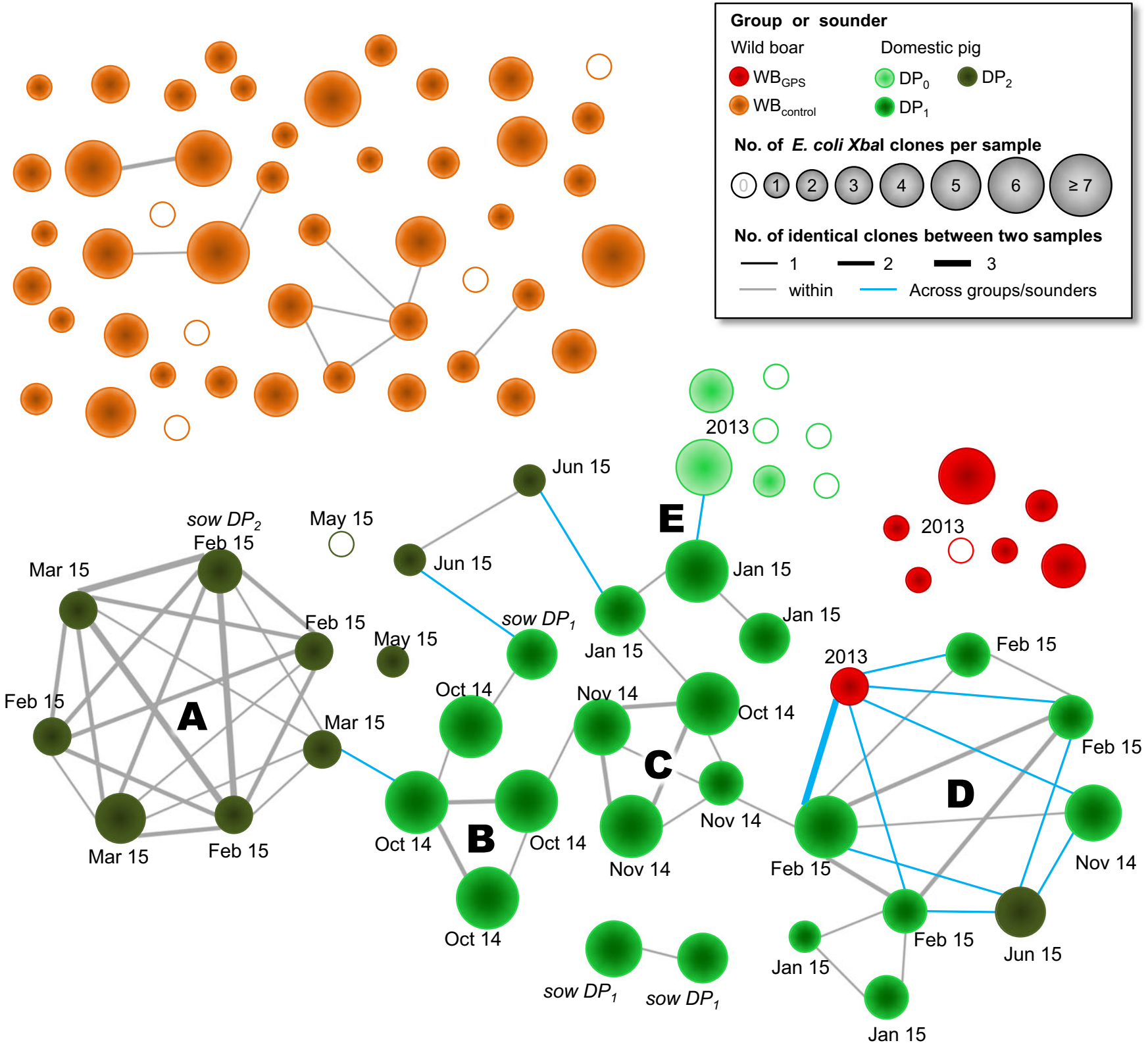

FIGURE 3 Occurrence of identical E. coli Xbal clones in faeces from wild boar and domestic pigs. Each circle stands for one faecal sample and represents the number of clones within the sample by the size of the circle. If identical $E$. coli Xbal clones occurred in different samples, the circles are connected by a line. For some samples, the collection date is given by month and year. Letters $A$ to $E$ refer to parts of the network that were discussed in the text

observational periods and on animals reared in intensive conditions only. For instance, the probiotic strain E. coli Nissle 1917 was shown to persist in pigs after experimental oral inoculation for at least 5 weeks, some E. coli pathotypes (STEC, EPEC, ETEC) for at least 2 months and some E. coli clones (based on biochemical profiling) over periods of 3-4 months (Barth et al., 2009; Booher, Cornick, \& Moon, 2002; Katouli et al., 1995). In the current study, of the 315 different identified E. coli Xbal clones, one clone was detected with a 7-month interval in one pig of group $\mathrm{DP}_{1}$ and $\mathrm{DP}_{2}$, respectively. One other clone was found with a gap of more than 1 year: once in one domestic pig in autumn 2013 during the sampling of the GPS collar wearing pigs of group $\mathrm{DP}_{0}$ and again in one piglet of sow $\mathrm{DP}_{1}$ in January 2015. These data indicate that a single E. coli clone can circulate among and persist in domestic free-range pig herds over several months or even years and confirms the suitability of this method as biological indicator during long-term monitoring studies.

Despite the small sample size, the recovery rate of $E$. coli clones from wild boar was high. E. coli were isolated in $87.5 \%$ of the wild boar sampled $(7 / 8)$ in the $\mathrm{WB}_{\mathrm{GPS}}$ group. With one to six E. coli clones per sample (mean 2.57), this number is slightly lower than in our previous study in captive animals (mean 3.00-3.63 E. coli clones per sample; [Barth et al., 2017]). From the animals of the $\mathrm{WB}_{\mathrm{GPS}}$ group, one wild boar excreted three individual E. coli Xbal clones; each of these clones was also found in at least two different 


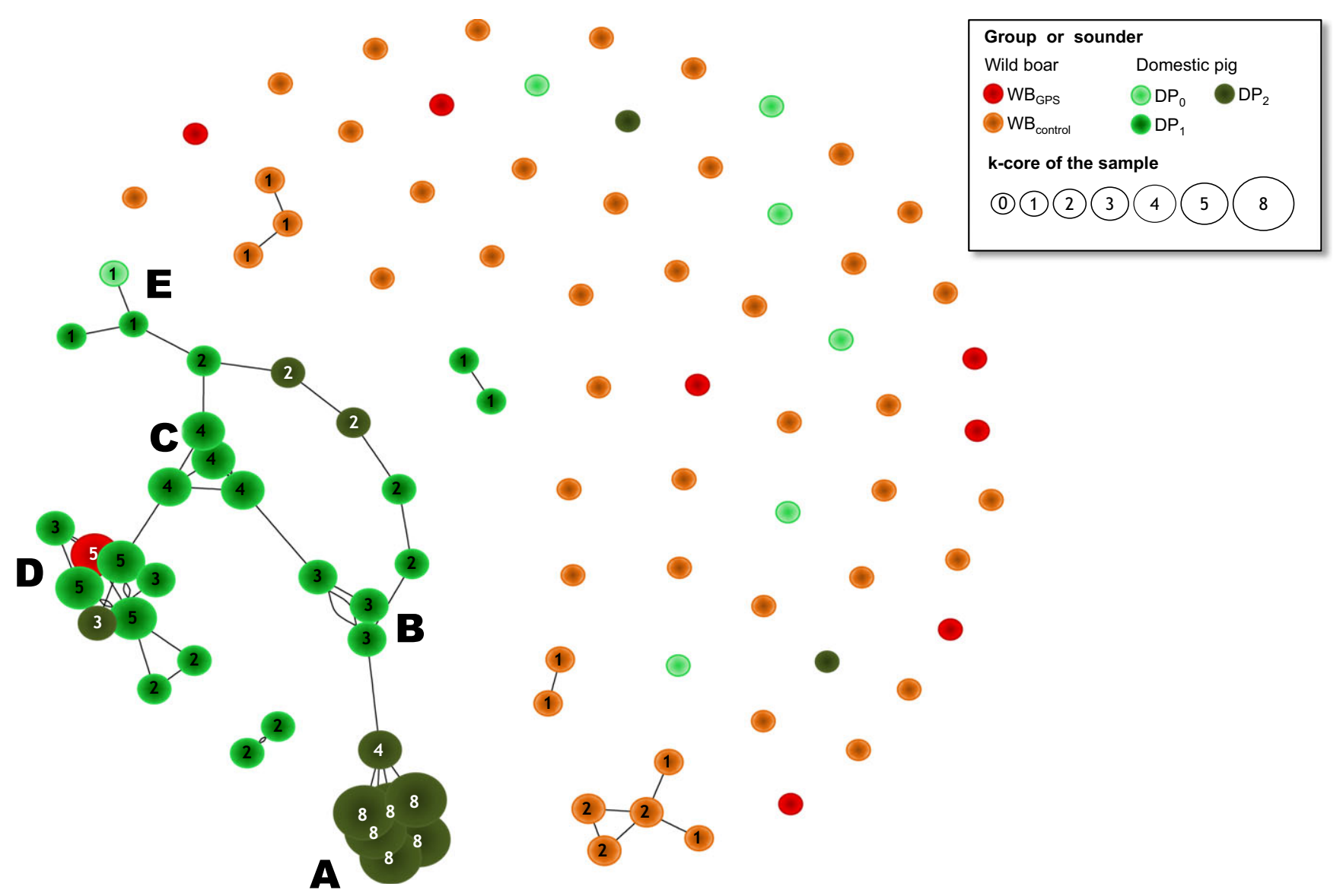

FIGURE 4 k-Core-based network of shared E. coli Xbal clones in faecal samples from wild boar and domestic pigs. Each circle stands for one faecal sample. The size of the circle represents the k-core (maximal subgraph containing nodes with at least $\mathrm{k}$-degrees). Letters $\mathrm{A}$ to $\mathrm{E}$ refer to parts of the network that were discussed in the text

domestic pigs of group $\mathrm{DP}_{1}$, directly connecting this wild boar with five different samples from $\mathrm{DP}_{1}$ pigs. None of the clones from the remaining $\mathrm{WB}_{\mathrm{GPS}}$ faecal samples were found in any other sample. Although a direct link to the domestic pigs tested was found in only one of eight tested $\mathrm{WB}_{\mathrm{GPS}}(12.5 \%)$, this interrelation was very intense as it encompassed the entire pig group tested (at least four different animals of group $\mathrm{DP}_{1}$ ), rather than only one animal. The clonality of the transmitted clones was confirmed using additional restriction enzymes targeting different recognition sites in the DNA sequence. A laboratory contamination between the samples was excluded as the samples were processed on different days. Similarly, in our previous experimental study, one clone present in the faeces of one donor wild boar was spread to different recipient domestic pigs, whereas other domestic pigs housed together in one pen did not acquire one of the wild boar clones (Barth et al., 2017). The likelihood of transmission and colonization may be influenced by diverse individual factors related to host behaviour (e.g., individual faecal shedding quantity of $E$. coli, or snuffling, wallowing and rooting behaviour) and bacterial properties (e.g., the capacity of the respective $E$. coli strain to survive in the environment [number of bacteria shed and their viability in faeces, environment or stomach during ingestion] or its endowment with genes affecting persistence).
In an experimental setting where frequent direct and indirect transmission of $\mathrm{O} 157$ clones was shown between piglets, the pigs were inoculated with bacterial doses $\left(5 \times 10^{8} \mathrm{cfu} /\right.$ dose) that presumably exceeded infectious doses that can be expected to occur under field conditions by far (Cornick \& VuKhac, 2008). In the current study, an intense transmission of $E$. coli $X b a l$ clones between sow $\mathrm{DP}_{2}$ and its offspring was obvious in the first 2 months after birth and supported by demonstration of the highest density level in the subnetwork $\mathrm{DP}_{2}$ with more than half of all possible interrelations. Conversely, only one link between the sow and one of her piglets directly after birth was shown in group $\mathrm{DP}_{1}$ by detection of an identical E. coli Xbal clone. Similar observations were made when PFGE $X b a l$ clones of CTX-M-producing $E$. coli were monitored in five sows and two of their respective piglets in an intensive pig production systems (Hansen, Bortolaia, Damborg, \& Guardabassi, 2014). To further support the method applied, none of the $127 \mathrm{E}$. coli Xbal clones from the wild boar control group $\left(\mathrm{WB}_{\text {control }}\right)$ clustered with one of the clones from the other groups, neither the GPS-tracked wild boar nor the domestic pigs. The low-density level of the $\mathrm{WB}_{\text {control }}$ subnetwork may be based on the fact that those animals belonged to several independent sounders. Overall, the heterogeneity of the selected E. coli clones allowed a clear discrimination of animal populations in 
different geographic regions. Taking into account the number of tobe-tested samples and clones and the tedious laboratory work, the method of identifying clones by PFGE still offers some advantages. It is reproducible and can be performed by different persons even in different laboratories, and many laboratories are capable of performing PFGE, as it has been used for 20 years to detect foodborne outbreaks, involving, for example, non-typhoidal Salmonella sp., E. coli O157:H7 or Listeria monocytogenes (Swaminathan, Barrett, Hunter, Tauxe, \& PulseNet Task Force, 2001). We conclude that the method applied was robust and sensitive enough for the current task of detecting possible contacts between wild boar and domestic pigs. In our study, E. coli is likely to be a good indicator of pathogen sharing between wild and domestic pigs in Mediterranean habitats, if they are transmitted via the faecal-oral route or if they are able to contaminate a shared environment, and infect wild and domestic animals and humans beings. These include, for instance, pathogens such as Salmonella sp. (Chiari, Zanoni, Tagliabue, Lavazza, \& Alborali, 2013), Leptospira sp. (Vale-Goncalves et al., 2015), Mycobacterium bovis (Naranjo, Gortazar, Vicente, \& de la Fuente, 2008) or the hepatitis E virus (Jori et al., 2016). In fact, a recent study in Corsica provided molecular evidence of transmission of hepatitis $E$ virus strains between wild boar and domestic pig populations (Jori et al., 2016). In that case, the study required the collection of organs and tissues obtained during hunting and slaughtering activities, which was logistically constraining. The $E$. coli method offers the possibility of using fresh faecal samples, which allows for identifying and characterizing locations prone to potential pathogen exchange between wild and domestic pigs without having to sample hunted or immobilized animals. Further studies should be applied to assess the potential of this non-invasive method in other epidemiological settings and with different pig-like species (Jori, Payne et al., 2017; Kukielka et al., 2016).

\section{ACKNOWLEDGEMENTS}

The research leading to these results has received funding from the European Union's Seventh Framework Programme (FP7/2007-2013) under grant agreement no. 311931 (ASFORCE).

\section{CONFLICT OF INTEREST}

The authors declare that no conflicts of interest exist.

\section{ORCID}
S. A. Barth (iD http://orcid.org/0000-0003-4921-5056
S. Blome iD http://orcid.org/0000-0001-5465-5609
M. Beer (iD) http://orcid.org/0000-0002-0598-5254
F. Jori iD http://orcid.org/0000-0001-5451-7767

\section{REFERENCES}

Albina, E., Mesplède, A., Chenut, G., Le Potier, M. F., Bourbao, G., Le Gal, S., \& Leforban, Y. (2000). A serological survey on classical swine fever
(CSF), Aujeszky's disease (AD) and porcine reproductive and respiratory syndrome (PRRS) virus infections in French wild boars from 1991 to 1998. Veterinary Microbiology, 77, 43-57. https://doi.org/10. 1016/S0378-1135(00)00255-8

Barth, S., Duncker, S., Hempe, J., Breves, G., Baljer, G., \& Bauerfeind, R. (2009). Escherichia coli Nissle 1917 for probiotic use in piglets: Evidence for intestinal colonization. Journal of Applied Microbiology, 107, 1697-1710. https://doi.org/10.1111/j.1365-2672.2009.04361.

Barth, S., Geue, L., Hinsching, A., Jenckel, M., Schlosser, J., Eiden, M., ... Blome, S. (2017). Experimental evaluation of faecal Escherichia coli and hepatitis $\mathrm{E}$ virus as biological indicators of contacts between domestic pigs and eurasian wild boar. Transboundary and Emerging Diseases, 64, 487-494. https://doi.org/10.1111/tbed.12389

Benhamou, S., \& Cornélis, D. (2010). Incorporating movement behavior and barriers to improve kernel home range space use estimates. Journal of Wildlife Management, 74, 1353-1360. https://doi.org/10.2193/ 2009-441

Booher, S. L., Cornick, N. A., \& Moon, H. W. (2002). Persistence of Escherichia coli $\mathrm{O} 157: \mathrm{H} 7$ in experimentally infected swine. Veterinary Microbiology, 89, 69-81. https://doi.org/10.1016/S0378-1135(02) 00176-1

Charrier, F., Rossi, S., Jori, F., Maestrini, O., Richomme, C., Casabianca, F., ... Le Potier, M. (2018). Aujeszky disease and hepatitis E viruses transmission between domestic pigs and wild boars in Corsica: Evaluating the importance of wild/domestic interface and the efficacy of management measures. Frontiers in Veterinary Science, in press.

Chiari, M., Zanoni, M., Tagliabue, S., Lavazza, A., \& Alborali, L. G. (2013). Salmonella serotypes in wild boars (Sus scrofa) hunted in northern Italy. Acta Veterinaria Scandinavica, 55, 42. https://doi.org/10.1186/ 1751-0147-55-42

Cornick, N. A., \& VuKhac, H. (2008). Indirect transmission of Escherichia coli 0157:H7 occurs readily among swine but not among sheep. Applied and Environment Microbiology, 74, 2488-2491. https://doi. org/10.1128/AEM.02897-07

De Sainte-Marie, C., \& Casabianca, F. (1998). Entre logique individuelle et intégration : "La fruitière », comme modèle d'organisation pour des producteurs ferliers de charcuterie Corse. INRA Editions. Études et Recherches sur les Systèmes Agraires et le Développement, pp. 297 315.

Dubost, M. (2001). Corse: Une montagne authentique et vivante. Le recensement 1999 des unités pastorales en Corse. Pastum, 6, 21-24.

Fortunato, S. (2010). Community detection in graphs. Physics Reports, 486, 75-174. https://doi.org/10.1016/j.physrep.2009.11.002

Fremaux, B., Prigent-Combaret, C., Delignette-Muller, M. L., Mallen, B., Dothal, M., Gleizal, A., \& Vernozy-Rozand, C. (2008). Persistence of Shiga toxin-producing Escherichia coli $\mathrm{O} 26$ in various manureamended soil types. Journal of Applied Microbiology, 104, 296-304. https://doi.org/11.1111/j.1365-2672.2007.03532.x

Germain, E., Benhamou, S., \& Poulle, M. L. (2008). Spatio-temporal sharing between the European wildcat, the domestic cat and their hybrids. Journal of Zoology, 276, 195-203. https://doi.org/10.1111/j. 1469-7998.2008.00479.x

Geue, L., Klare, S., Schnick, C., Mintel, B., Meyer, K., \& Conraths, F. J. (2009). Analysis of the clonal relationship of serotype O26:H11 enterohemorrhagic Escherichia coli isolates from cattle. Applied and Environment Microbiology, 75, 6947-6953. https://doi.org/10.1128/ AEM.00605-09

Geue, L., Schares, S., Mintel, B., Conraths, F. J., Müller, E., \& Ehricht, R. (2010). Rapid microarray-based genotyping of enterohemorrhagic Escherichia coli serotype $\mathrm{O} 156 \mathrm{H} 25 / \mathrm{H}$-/Hnt isolates from cattle and clonal relationship analysis. Applied and Environment Microbiology, 76, 5510-5519. https://doi.org/10.1128/AEM.00743-10

Gordon, D. M., \& Cowling, A. (2003). The distribution and genetic structure of Escherichia coli in Australian vertebrates: Host and geographic 
effects. Microbiology, 149, 3575-3586. https://doi.org/10.1099/mic. 0.26486-0

Hansen, K. H., Bortolaia, V., Damborg, P., \& Guardabassi, L. (2014). Strain diversity of CTX-M-producing Enterobacteriaceae in individual pigs: Insights into the dynamics of shedding during the production cycle. Applied and Environment Microbiology, 80, 6620-6626. https://doi. org/10.1128/AEM.01730-14

Jori, F., Laval, M., Maestrini, O., Casabianca, F., Charrier, F., \& Pavio, N. (2016). Assessment of domestic pigs, wild boars and feral hybrid pigs as Reservoirs of hepatitis E virus in Corsica, France. Viruses, 8, 236. https://doi.org/10.3390/v8080236

Jori, F., Payne, A., Kock, R., Nava, A., Ståhl, K., \& Rossi, S. (2017). Wild and feral pigs: Disease transmission at the interface between wild and domestic Suiform species in the Old and the New World. In M. Melletti, \& E. Meijaard (Eds.), Ecology, evolution and management of wild pigs and peccaries. Cambridge, UK: Cambridge University Press.

Jori, F., Relun, A., Trabucco, B., Charrier, F., Maestrini, O., Chavernac, D., .. Etter, E. M. C. (2017). Questionnaire-based assessment of wild boar/domestic pig interactions and implications for disease risk management in Corsica. Frontiers in Veterinary Science, 4, 198. https://doi. org/10.3389/fvets.2017.00198

Katouli, M., Lund, A., Wallgren, P., Kühn, I., Söderlind, O., \& Möllby, R. (1995). Phenotypic characterization of intestinal Escherichia coli of pigs during suckling, postweaning, and fattening periods. Applied and Environment Microbiology, 61, 778-783.

Kukielka, E. A., Jori, F., Martinez-Lopez, B., Chenais, E., Masembe, C., Chavernac, D., \& Stahl, K. (2016). Wild and domestic pig interactions at the wildlife-livestock interface of murchison falls National Park, Uganda, and the potential association with African Swine fever outbreaks. Frontiers in Veterinary Science, 3, 31. https://doi.org/10.3389/ fvets.2016.00031

Liebana, E., Smith, R. P., Batchelor, M., McLaren, I., Cassar, C., CliftonHadley, F. A., \& Paiba, G. A. (2005). Persistence of Escherichia coli O157 isolates on bovine farms in England and Wales. Journal of Clinical Microbiology, 43, 898-902. https://doi.org/10.1128/JCM.43.2. 898-902.2005

Meng, X. J., Lindsay, D. S., \& Sriranganathan, N. (2009). Wild boars as sources for infectious diseases in livestock and humans. Philosophical Transactions of the Royal Society of London B: Biological Sciences, 364, 2697-2707. https://doi.org/10.1098/rstb.2009.0086

Mercat, M., Clermont, O., Massot, M., Ruppe, E., de Garine-Wichatitsky, M., Miguel, E., ... Caron, A. (2016). Escherichia coli population structure and antibiotic resistance at a buffalo/cattle interface in Southern Africa. Applied and Environment Microbiology, 82, 1459-1467. https://doi.org/10.1128/AEM.03771-15

Mur, L., Atzeni, M., Martinez-Lopez, B., Feliziani, F., Rolesu, S., \& Sanchez-Vizcaino, J. M. (2016). Thirty-five-year presence of african Swine fever in Sardinia: History, evolution and risk factors for disease maintenance. Transboundary and Emerging Diseases, 63, E165-E177. https://doi.org/10.1111/tbed.12264

Naranjo, V., Gortazar, C., Vicente, J., \& de la Fuente, J. (2008). Evidence of the role of European wild boar as a reservoir of Mycobacterium tuberculosis complex. Veterinary Microbiology, 127, 1-9. https://doi. org/10.1016/j.vetmic.2007.10.002

ONCFS (2012). Tableaux de chasse ongulés sauvages saison 2011-2012. Supplément Faunae Sauvage, 296, 1-8.

Pavio, N., Laval, M., Maestrini, O., Casabianca, F., Charrier, F., \& Jori, F. (2016). Possible foodborne transmission of hepatitis $E$ virus from domestic pigs and wild boars from Corsica. Emerging Infectious Diseases, 22, 2197-2199. https://doi.org/10.3201/eid2212.160612

Pepin, K. M., Davis, A. J., Beasley, J., Boughton, R., Campbell, T., Cooper, S. M., ... VerCauteren, K. C. (2016). Contact heterogeneities in feral swine: Implications for disease management and future research. Ecosphere, 7, e01230. https://doi.org/10.1002/ecs2.1230
Pesapane, R., Ponder, M., \& Alexander, K. A. (2013). Tracking pathogen transmission at the human-wildlife interface: Banded mongoose and Escherichia coli. EcoHealth, 10, 115-128. https://doi.org/10.1007/ s10393-013-0838-2

R Core Team (2016). R: A language and environment for statistical computing (R.app GUI 1.69). Vienna, Austria: R Foundation for Statistical Computing. Retrieved from http://www.R-project.org/.

Relun, A., Charrier, F., Trabucco, B., Maestrini, O., Molia, S., Chavernac, D., ... Jori, F. (2015). Multivariate analysis of traditional pig management practices and their potential impact on the spread of infectious diseases in Corsica. Preventive Veterinary Medicine, 121, 246-256. https://doi.org/10.1016/j.prevetmed.2015.07.004

Richomme, C., Boadella, M., Courcoul, A., Durand, B., Drapeau, A., Corde, Y., .. Boschiroli, M. L. (2013). Exposure of wild boar to Mycobacterium tuberculosis complex in France since 2000 is consistent with the distribution of bovine tuberculosis outbreaks in cattle. PLoS ONE, 8, e77842. https://doi.org/10.1371/journal.pone.0077842

Richomme, C., Boschiroli, M. L., Hars, J., Casabianca, F., \& Ducrot, C. (2010). Bovine tuberculosis in livestock and wild boar on the Mediterranean island, Corsica. Journal of Wildlife Diseases, 46, 627631. https://doi.org/10.7589/0090-3558-46.2.627

Richomme, C., Lacour, S. A., Ducrot, C., Gilot-Fromont, E., Casabianca, F., Maestrini, O., ... Boireau, P. (2010). Epidemiological survey of trichinellosis in wild boar (Sus scrofa) and fox (Vulpes vulpes) in a French insular region, Corsica. Veterinary Parasitology, 172, 150-154. https://doi.org/10.1016/j.vetpar.2010.04.026

Rödiger, S., Kramer, T., Frömmel, U., Weinreich, J., Roggenbuck, D., Guenther, S., ... Schierack, P. (2015). Intestinal Escherichia coli colonization in a mallard duck population over four consecutive winter seasons. Environmental Microbiology, 17, 3352-3361. https://doi.org/ 10.1111/1462-2920.12807

Ruiz-Fons, F., Segalés, J., \& Gortázar, C. (2008). A review of viral diseases of the European wild boar: Effects of population dynamics and reservoir role. Veterinary Journal, 176, 158-169. https://doi.org/10.1016/j. tvjl.2007.02.017

Rwego, I. B., Gillespie, T. R., Isabirye-Basuta, G., \& Goldberg, T. L. (2008). High rates of Escherichia coli transmission between livestock and humans in rural Uganda. Journal of Clinical Microbiology, 46, 3187 3191. https://doi.org/10.1128/JCM.00285-08

Rwego, I. B., Isabirye-Basuta, G., Gillespie, T. R., \& Goldberg, T. L. (2008). Gastrointestinal bacterial transmission among humans, mountain gorillas, and livestock in Bwindi Impenetrable National Park, Uganda. Conservation Biology, 22, 1600-1607. https://doi.org/10.1111/j.15231739.2008.01018.x

Sánchez, S., Martinez, R., Garcia, A., Blanco, J., Blanco, J. E., Blanco, M., ... Alonso, J. M. (2009). Longitudinal study of Shiga toxin-producing Escherichia coli shedding in sheep feces: Persistence of specific clones in sheep flocks. Applied and Environment Microbiology, 75, 17691773. https://doi.org/10.1128/AEM.02043-08

Schierack, P., Walk, N., Reiter, K., Weyrauch, K. D., \& Wieler, L. H. (2007). Composition of intestinal Enterobacteriaceae populations of healthy domestic pigs. Microbiology, 153, 3830-3837. https://doi.org/ 10.1099/mic.0.2007/010173-0

Springer, A., Mellmann, A., Fichtel, C., \& Kappeler, P. M. (2016). Social structure and Escherichia coli sharing in a group-living wild primate, Verreaux's sifaka. BMC Ecology, 16, 6. https://doi.org/10.1186/ s12898-016-0059-y

Swaminathan, B., Barrett, T. J., Hunter, S. B., Tauxe, R. V., \& PulseNet Task Force, C. D. C. (2001). PulseNet: The molecular subtyping network for foodborne bacterial disease surveillance, United States. Emerging Infectious Diseases, 7, 382-389. https://doi.org/10.3201/eid 0703.010303

Tenover, F. C., Arbeit, R. D., Goering, R. V., Mickelsen, P. A., Murray, B. E., Persing, D. H., \& Swaminathan, B. (1995). Interpreting chromosomal DNA restriction patterns produced by pulsed-field gel 
electrophoresis: Criteria for bacterial strain typing. Journal of Clinical Microbiology, 33, 2233-2239.

Trabucco, B., Charrier, F., Jori, F., Maestrini, O., Cornelis, D., Etter, E., ... Casabianca, F. (2014). Stakeholder's practices and representations of contact between domestic and wild pigs: A new approach for disease risk assessment? Acta Agriculturae Slovenica Supplement, 4, 117-122.

Vale-Goncalves, H. M., Cabral, J. A., Faria, M. C., Nunes-Pereira, M., Faria, A. S., Veloso, O., ... Paiva-Cardoso, M. N. (2015). Prevalence of Leptospira antibodies in wild boars (Sus scrofa) from Northern Portugal: Risk factor analysis. Epidemiology and Infection, 143, 21262130. https://doi.org/10.1017/S0950268814003331

VanderWaal, K. L., Atwill, E. R., Isbell, L. A., \& McCowan, B. (2014). Linking social and pathogen transmission networks using microbial genetics in giraffe (Giraffa camelopardalis). Journal of Animal Ecology, 83, 406-414. https://doi.org/10.1111/1365-2656.12137

Wyckoff, A. C., Henke, S. E., Campbell, T. A., Hewitt, D. G., \& VerCauteren, K. C. (2009). Feral swine contact with domestic swine: A serologic survey and assessment of potential for disease transmission.
Journal of Wildlife Diseases, 45, 422-429. https://doi.org/10.7589/ 0090-3558-45.2.422

\section{SUPPORTING INFORMATION}

Additional Supporting Information may be found online in the supporting information tab for this article.

How to cite this article: Barth SA, Blome S, Cornelis D, et al. Faecal Escherichia coli as biological indicator of spatial interaction between domestic pigs and wild boar (Sus scrofa) in Corsica. Transbound Emerg Dis. 2018;00:1-12. https://doi.org/10.1111/tbed.12799 